\title{
Serological evidence of Zika virus infection in febrile patients at Greater Accra Regional Hospital, Accra Ghana
}

Godson Aryee Ankrah', Joseph Humphrey Kofi Bonney ${ }^{2 *}$ (D), Esinam Eudosia Agbosu², Deborah Pratt ${ }^{2}$ and Theophilus Korku Adiku1,3

\begin{abstract}
Objective: Increase in the evidence of global occurrence of Zika viral infection suggests that in Africa the circulation of the virus which causes $80 \%$ of asymptomatic infection could be undetected and/or overlooked. We sought to serologically detect Zika virus infection in febrile patients at Greater Accra Regional Hospital, Ghana.

Results: Of the 160 patient serum samples analyzed, 33 were found to have antibodies against Zika virus infection. Among the sero-positives 30 (91\%) of the cases were anti-Zika virus IgM with the 21-30-year age group recording the highest number of 8 (26\%) and 2 (7\%) cases being the least for the 61 years and above age group. All sero-positive febrile patients developed at least one symptom consistent with Zika virus infection: 33 (100\%) fever, 25 (76\%) muscle pain, 24 (73\%) joint pain, and conjunctivitis 2 (6\%). Digestive symptoms recorded include 16 (49\%) nausea, 12 (36\%) vomiting and diarrhea 18 (55\%). In addition, 28 (85\%) loss of appetite, 14 (75\%) rapid respiration and chest pain 15 (42\%) were reported by seropositive febrile patients. Our data indicates exposure to Zika virus which suggests the possible circulation of the virus among febrile patients in Ghana with a sero-prevalence rate of $20.6 \%$.
\end{abstract}

Keywords: Zika virus, Seroprevalence, Anti-Zika virus immunoglobulins M and G (IgM and lgG) antibodies, Enzyme linked immunosorbent assay (ELISA)

\section{Introduction}

Febrile illnesses account for about $30 \%$ and $75 \%$ of healthcare visit by children [1] and adults [2] respectively in Ghana. However, these febrile illnesses are mostly misdiagnosed for endemic diseases, malaria and typhoid fever. Zika virus infection shares overlapping signs and symptoms with most endemic diseases including malaria and typhoid fever. The etiologic agent, Zika virus was first isolated in Uganda in 1947 from a rhesus macaque monkey and Aedes africanus mosquito in 1948 [3]. First human cases of Zika virus infection were reported in Africa and Asia. In Africa, Zika virus infection was documented in Uganda and Tanzania in 1952

\footnotetext{
*Correspondence: Kbonney@noguchi.ug.edu.gh

${ }^{2}$ Virology Department, Noguchi Memorial Institute for Medical Research, College of Health Sciences, University of Ghana, P.O. Box LG 581, Legon, Accra, Ghana

Full list of author information is available at the end of the article
}

[4] and in Asia, notably Indonesia, Malaysia and Thailand [5]. Afterwards serological studies detected Zika virus infection in humans in Nigeria, Egypt, India, Pakistan, North Vietnam and Philippines, spreading from Africa to Southeast Asia [6, 7]. Zika virus infection in Africa and Asia never got the deserved attention due to the sporadic nature of the infection coupled with mild short-term and low-grade fever $\left(37.8-38.5^{\circ} \mathrm{C}\right)$ and mostly self-limiting symptoms including maculopapular and pruritic rashes, conjunctivitis (non-purulent) and arthralgia [8]. As a result, Zika virus infection appeared to have been neglected in tropical medicine and no efforts were made to develop vaccine and drugs for treatment [7]. Although Zika virus infection has not been reported in Ghana, evidence of several outbreaks and exposure to the virus have been reported in various African countries such as Gabon [9] Cape Verde, Senegal [10, 11] and Ivory Coast which share a common border with Ghana. Thus, the evidence of exposure to the virus in our neighboring 
countries and the presence of active vector population of Aedes spp. of mosquitoes in Ghana have necessitated the need to document the exposure levels in febrile patients. The mild or asymptomatic nature and the overlapping clinical feature with other endemic disease conditions make it probable for typical Zika virus infection to be missed out in diagnosis. Therefore, we set out to augment and improve scientific data in the sub-region and create awareness to pre-empt possible outbreaks with the detection of antibodies against Zika virus circulating among febrile patients at Greater Accra Regional Hospital, Accra Ghana.

\section{Main text \\ Methods \\ Study design}

This was a cross sectional study that involved 160 archived serum samples from febrile patients at the Greater Accra Regional Hospital between December 2016 and November 2017. These clinical specimens were obtained as part of an ongoing project with the aim of using serological and molecular tools to detect Dengue, Chikungunya and other Arboviruses in febrile patients within selected health facilities in Ghana. A structured case investigation form was used to collect information about demographic features, and clinical signs and symptoms of the febrile patients.

\section{Eligibility criteria}

Inclusion criteria for enrollment included a person with fever (body temperature above $38{ }^{\circ} \mathrm{C}$ ) and at least one of the following signs or symptoms: arthralgia; or arthritis; or conjunctivitis (non-purulent/hyperemic). Patients positive for malaria by blood film diagnosis and patients who refuse to submit samples after consenting were excluded from the study. Venous blood was collected into heparinized tubes and centrifuged, and serum was harvested, aliquoted into two separate cryogenic $1.8 \mathrm{ml}$ vials for each patient sample and stored at $-80^{\circ} \mathrm{C}$.

\section{Laboratory testing}

The archived sera from febrile patients were tested by enzyme linked immunosorbent assay (ELISA) for antiZika virus IgM and IgG antibodies with a commercial ELISA kit, Zika virus IgM and IgG capture ELISA (Abcam, Cambridge, UK). The sensitivity of this ELISA kit used (Abcam anti-Zika virus IgM and IgG) was reportedly assessed by evaluating the performances of 5 commonly used Zika virus immunoassays against an ELISA (MAC ELISA) developed by the US Centers for Disease Control and Prevention and cross-Plaque reduction neutralization test (PRNT) was reported as $57 \%$ and a specificity of $100 \%$ [12]. Manufacturer's instructions or recommendations were followed in all tests performed.

Zika virus IgM and IgG negative control, Zika virus IgM and IgG positive control and the test serum samples were first diluted with sample dilution buffer for Zika virus IgM and IgG. Thereafter, incubated at $37^{\circ} \mathrm{C}$ for an hour in micro-titre plates pre-coated with monoclonal antibody bound to recombinant Zika virus antigen. After subsequent washing, wells were treated with horseradish peroxidase (HRP) Zika virus conjugate (peroxidase labeled Zika virus antigen) except for the substrate blank well and incubated for $30 \mathrm{~min}$ at $37{ }^{\circ} \mathrm{C}$. Washing was repeated after which substrate solution $3,3^{\prime}, 5,5^{\prime}$-tetramethylbenzidine (TBM) hydrogen peroxide was added and incubated in the dark at room temperature $20-25^{\circ} \mathrm{C}$ for $15 \mathrm{~min}$. A stop solution was then added, and the absorbance measured at $450 \mathrm{~nm}$ using ELISA microtiter plate reader (Human Diagnostic Worldwide, Germany) within $30 \mathrm{~min}$ after terminating the reaction using a reference wavelength of $620 \mathrm{~nm}$. The ELISA tests results were classified according to the interpretation provided by the supplier, Abcam, Cambridge, UK.

\section{Statistical analysis}

One Way-Anova was used to test the association within groups at significance level of $\mathrm{P}$-value $<0.05$ using SPSS version 20.

\section{Results}

\section{Characteristics of Zika virus sero-positives}

Of the 160 samples tested, 33 (20.6\%) had positive serological evidence for Zika virus. Out of the 33 Zika virus sero-positives, 30 (90.9\%) were IgM positive whereas 3 (9.1\%) were IgG positive. Of all the patients enrolled, 119 (74.4\%) were females while 41 (25.6\%) were males. Number of anti-Zika virus IgM males was $11(36.7 \%)$ and that of females was 19 (63.3\%) (Table 1). Anti-Zika virus IgG antibodies were detected only in females, however Zika virus infection was observed to affect males and females in a ratio of 1:2. Among the age groups identified, 8 $(26.7 \%)$ of the anti-Zika virus IgM were recorded in age group 21-30 with 2 (6.7\%) for the age group 61 years and above (Table 1). Anti-Zika virus IgG antibodies were detected only in age groups 21-30 2 (66.7\%) and 41-50 1 (33.4\%) (Table 1). There was significant difference between anti-Zika virus IgM among the age groups $(\mathrm{P}=0.004)$.

\section{Monthly distribution of Zika virus antibodies}

Anti-Zika virus IgM detection peaked in March 7 (23.3\%) and May 9 (30\%) and lowed in September 1 (3.3\%). However, anti-Zika virus IgG antibodies were detected only in 
Table 1 Demographic distribution of seropositive febrile patients

\begin{tabular}{llll}
\hline Variables & \multicolumn{4}{l}{ Zika virus antibodies, $\mathrm{n}=33$} \\
\cline { 2 - 4 } & $\operatorname{lgM}(30) \quad P$-value $\quad \operatorname{lgG}(3)$ & $P$-value \\
\hline
\end{tabular}

\begin{tabular}{lllll}
\hline $\begin{array}{llll}\text { Age groups } \\
3-20\end{array}$ & $4(13 \%)$ & 0 & & \\
$21-30$ & $8(26.7 \%)$ & $2(66.7 \%)$ & & \\
$31-40$ & $6(20 \%)$ & & 0 & \\
$41-50$ & $7(23.3 \%)$ & $0.004^{*}$ & $1(33.3)$ & 0.203 \\
$51-60$ & $3(10 \%)$ & & 0 & \\
61 and above & $2(6.7 \%)$ & 0 & & \\
Gender & & & & \\
Male & $11(36.7 \%)$ & & 0 & \\
Female & $19(63.3 \%)$ & 0.166 & $3(100 \%)$ & 0.500
\end{tabular}

$n$ number of Zika virus seropositive

* Statistically significant difference between age groups $(P=0.004) . P$ is significant at 0.05

January and March 2 (66.7\%) and 1 (33.3\%) respectively (Fig. 1).

\section{Symptoms presented by seropositive febrile patients}

Thirty-three $(100 \%)$ of the seropositive febrile patients were presented with fever. The least $1(0.8 \%)$ symptom reported was conjunctivitis which was also not reported by any seropositive Zika virus female. All other symptoms were reported in both males and females (Table 2).

\section{Discussion}

The results from the study indicate exposure levels to Zika virus which suggest the possible circulation of the virus among febrile patients in Ghana with a sero-prevalence of $20.6 \%$. Anti-Zika virus IgM prevalence observed is likely due to the recent (in the year 2016) wave of Zika
Table 2 Symptoms and complications of Zika virus seropositives $(n=33)$

\begin{tabular}{llc}
\hline Symptoms & Zika positive cases & Percentage \\
\hline Fever & 33 & 100 \\
Diarrhea & 18 & 55 \\
Nausea & 16 & 49 \\
Vomiting & 12 & 36 \\
Loss of appetite & 28 & 85 \\
Muscle pain & 25 & 76 \\
Joint pain & 24 & 73 \\
Conjunctivitis & 2 & 6 \\
Chest pain & 15 & 46 \\
Rapid respiration & 14 & 42 \\
Jaundice & 1 & 3 \\
Recent hearing loss & 1 & 3 \\
\hline
\end{tabular}

virus infection dominated headlines in certain parts of the world, especially those with tropical climate. Data presented by this study again suggests noticeable levels of susceptibility to Zika virus infections. This could mean many infected women subjects being at risk of giving birth to babies with defects. Thus, an extended scope to cover infected expectant mothers and diagnose birth defects would have been interesting and will be considered in further studies.

The sero-prevalence of Zika virus antibodies of 20.6\% in this study was consistent with study findings from other African countries with a rate from as low as $0.1 \%$ in Gabon and Senegal and as high as 38\% in Cameroon [13]. These differences could be due to inconsistency in the study participants' inclusion criteria or diagnostic test used. Zika virus infection was estimated to affect females and males in a ratio of 2:1 which correlate well with several studies [14]. Considering the findings of [14] and that of this study, there may be gender-related differences in

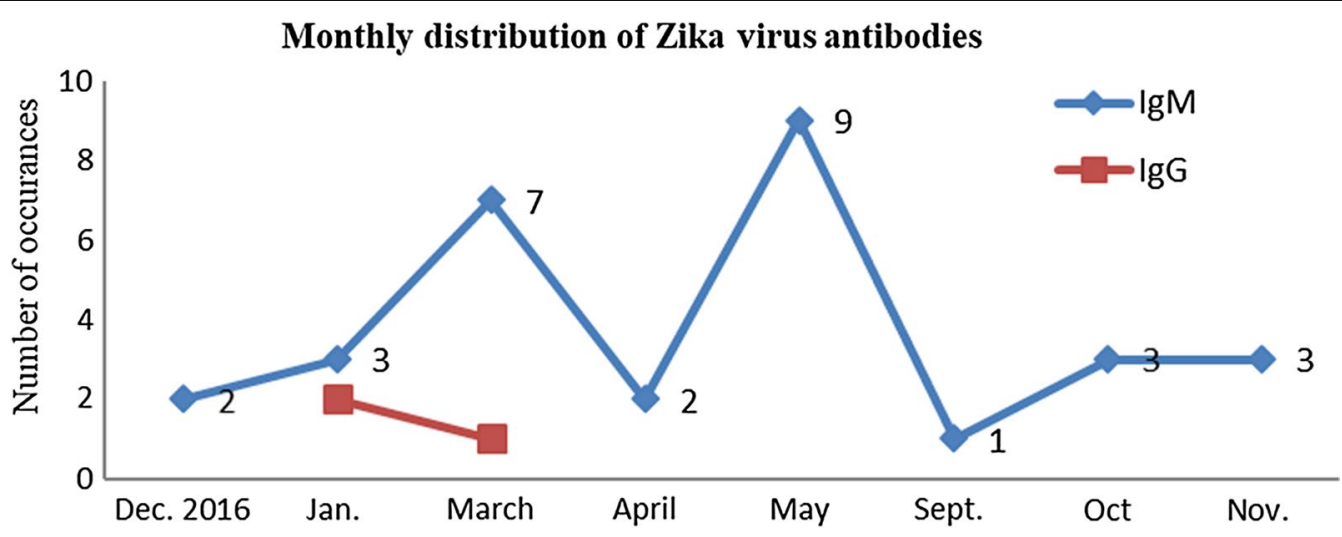

Fig. 1 Monthly distribution of Zika virus antibodies 
Zika virus infection incidence, which might be due to exposure differences [15]. Activeness of females during the early hours of the day exposes greater proportion of females to Zika virus-carrying Aedes spp. of mosquitoes either at work or while travelling to and from work. This may also be attributed to possible differences in who sought medical care following symptomatic Zika virus infection. High prevalence of IgM or IgG in age group 21-30 compared to 61 and above support data from earlier studies by [14] and [16]. Possible explanation to this observation could be the activeness of age group 21-30 during the early hours of the day which exposes them to the bites of Zika virus-carrying Aedes spp. of mosquitoes more frequently than age group 61 years and above. This could also suggest adults manifest with disease less, as they become immune to Zika virus. The proportions of the IgG antibody titers recorded in age group 21-30 and 41-50 may suggest that, Zika virus infection is not endemic in Ghana, rather the virus had been introduced to a non-exposed population as endemicity is attained when the adult infection decreases and only the new entrants into the population are affected more [16]. The significant difference between IgM among the age groups may be due to the pattern of erotic activities and exposure among the age groups. Active sexual activity and exposure begins early, increases simultaneously and declines as one ages. Monthly distribution of Zika virus infection with higher prevalence in the raining season as seen in this study is in harmony with reported pattern of Zika virus transmission [17]. The high frequency of IgM in the month of May and March could be due to the high amount of rainfall which provided temperatures suitable for virus survival, incubation, development and biting of Aedes aegypti and Aedes albopictus [18]. The compact clusters of cases in March and May, and the high prevalence of IgM against Zika virus are consistent with an acute outbreak of Zika virus infection in the population without previous immunity to Zika virus [19]. In this study, commonly reported symptoms of Zika virus infection documented were fever, muscle pain, joint pain and conjunctivitis. Strikingly, conjunctivitis often observed in Zika virus infection was not reported by any seropositive female. Digestive symptoms noted in Zika virus infected patients but rarely observed [20], however, found in this study were nausea, vomiting and diarrhea.

\section{Limitation}

The limitation of this study was the absence of plaque neutralization reduction test and PCR for confirmation.

\section{Abbreviations}

AMED: Japan Agency for Medical Research and Development; ELISA: enzyme-linked immunosorbent assay; HRP: horseradish peroxidase; IgG/M: immunoglobulin G/M; J-GRID: Japan Initiative for Global Research Network on Infectious Diseases; NMIMR: Noguchi Memorial Institute for Medical Research; TBM: 3,3',5,5'-tetramethylbenzidine; US CDC: United States of America's Centers for Disease Control and Prevention.

\section{Acknowledgements}

We are grateful to the clinicians and paramedical staff of the Public Health Division of Greater Accra Regional Hospital, Ridge for their technical assistance, the administrative support from the head and staff of the Department of Microbiology, University of Ghana, Korle Bu and Department of Virology at Noguchi Memorial Institute for Medical Research.

\section{Authors' contributions}

Conceived and designed the experiments: TKA, JHKB, GAA; Performed the experiments: GAA, JHKB, DP EEA; Analyzed the data: GAA, JHKB, DP, EEA; Contributed reagents/materials: JHKB; Wrote the paper: GAA, JHKB; Revised and edited manuscript: GAA, JHKB, TKA, DP, EEA. All authors read and approved the final manuscript.

\section{Funding}

This work was supported partly by funds from the Japan Initiative for Global Research Network on Infectious Diseases (J-GRID) from the Japan Agency for Medical Research and Development (AMED) and by the Government of Ghana through financial support from the University of Ghana Research Fund. The funders did not contribute to the design of the study and collection, analysis, and interpretation of data and in writing the manuscript. This study was funded by Japan Agency for Medical Research and Development (AMED) and by the Government of Ghana through financial support from the University of Ghana Research Fund (JP18fm0108010).

\section{Availability of data and materials}

In this manuscript, the availability of data and material was not applicable.

\section{Ethics approval and consent to participate}

The study was approved by both Institutional review Committees of the College of health Sciences, University of Ghana and Noguchi Memorial Institute for Medical Research. A written consent was obtained from all eligible adult patients or guardians of patients less than 18 years old before inclusion. All study participants were assigned with unique identification number throughout the study.

\section{Consent for publication}

Not applicable.

\section{Competing interests}

The authors declare that they have no competing interests.

\section{Author details}

${ }^{1}$ Department of Medical Microbiology, College of Health Sciences, University of Ghana, Korle Bu, Accra, Ghana. ${ }^{2}$ Virology Department, Noguchi Memorial Institute for Medical Research, College of Health Sciences, University of Ghana, P.O. Box LG 581, Legon, Accra, Ghana. ${ }^{3}$ Department of Biomedical Sciences, University of Health and Allied Sciences, Ho, Volta Region, Ghana.

Received: 30 April 2019 Accepted: 5 June 2019

Published online: 10 June 2019

References

1. Section on Clinical Pharmacology and, Therapeutics; Committee on, Drugs, Farrar HC, Sullivan JE. Fever and antipyretic use in children. Pediatrics. 2011;127(3):580-7.

2. Kiekkas P, Aretha D, Bakalis N, Karpouhtsi I, Marneras C, Baltopoulos Gl. Fever effects and treatment in critical care: literature review. Aust Crit Care. 2012;26(3):130-5. https://doi.org/10.1016/j.aucc.2012.10.004.

3. Duffy, Chen TH, Hancock WT, Powers AM, Kool JL, Lanciotti RS, Pretrick M, Marfel M, Holzbauer S, Dubray C, Guillaumot L, Griggs A, Bel MA, Lambert AJ, Laven J, Kosoy O, Panella A, Biggersta BJ, Fischer M, Hayes EB. Zika virus outbreak on Yap Island, federated states of Micronesia. N Engl J Med. 2009;360:2536-43. 
4. Haddow AD, Schuh AJ, Yasuda CY, Kasper MR, Heang V, Huy R. Genetic characterization of Zika virus strains: geographic expansion of the Asian lineage. PLoS Negl Trop Dis. 2012;6:e1477.

5. Hayes EB. Zika virus outside Africa. Emerg Infect Dis. 2009;15(9):1347-50.

6. Calveta GA, Filippis AM, Mendonça MC, Sequeira PC, Siqueira AM, Veloso $V G$, et al. First detection of autochthonous Zika virus transmission in a HIV-infected patient in Rio de Janeiro, Brazil. J Clin Virol. 2016;74:1-3.

7. Lanciotti RS, Kosoy OL, Laven JJ, Velez JO, Lambert AJ, Johnson AJ, Stanfield SM, Duffy MR. Genetic and serologic properties of Zika virus associated with an epidemic, Yap State, Micronesia, 2007. Emerg Infect Dis. 2008;14(8):1232-9.

8. Brasil P, Pereira JP, Gabaglia RC, Damasceno L, Wakimoto M, RibeiroNogueira RM, et al. Zika virus infection in pregnant women in Rio de Janeiro_-preliminary report. N Engl J Med. 2016; NEJMoa1602412. https ://doi.org/10.1056/nejmoa1602412.

9. Grard G, Caron M, Mombo IM, Nkoghe D, MbouiOndo S, Jiolle D, et al. Zika virus in Gabon (Central Africa)-2007: a new threat from Aedes albopictus? PLoS Negl Trop Dis. 2014;8:e2681.

10. Heang V, Yasuda CY, Sovann L, Haddow AD, Travassosda-Rosa AP, Tesh RB, et al. Zika virus infection, Cambodia, 2010. Emerg Infect Dis. 2012;18:349-51.

11. Heang V, Yasuda C, Ngan C, et al. Zika virus from fever syndromic surveillance in Cambodia. Am J Trop Med Hyg. 2011;85(6 suppl 1):183.

12. Safronetz D, Sloan A, Stein DR, Mendoza E, Barairo N, Ranadheera C, Scharikow L, Holloway K, Robinson A, Traykova-Andonova M, Makowski K, Dimitrova K, Giles E, Hiebert J, Mogk R, Beddome S, Drebot M. Evaluation of 5 commercially available Zika virus immunoassays. Emerg Infect Dis. 2017;23(9):1577-80

13. Saiz J-C, Vázquez-Calvo Á, Blázquez AB, Merino-Ramos T, EscribanoRomero E, Martín-Acebes MA. Zika virus: the latest newcomer. Front Microbiol. 2016;7:496. https://doi.org/10.3389/fmicb.2016.00496.
14. Matthew JL, Rachal MB, Lopez J, Acevedo V, Amador M, Read JS, Jara A, Waterman SH, Barrera R, Muñoz-Jordan J. Prevalence of symptomatic Zika virus infection by age and sex_Puerto Rico, 2016. J Infect Dis. jix630. https://doi.org/10.1093/infdis/jix630. 2017. ISSN 1537-6613.

15. Kaplan JE, et al. Epidemiologic investigations of dengue infection in Mexico. Am J Epidemiol. 1983;117:335-43.

16. Kumar M, Sharma R, Parihar G, Sharma M. Seroprevalence of dengue in central Rajasthan: a study at a tertiary care hospital. Int J Curr Microbiol Appl Sci. ISSN: 2319-7706. 2015;4(9): 933-40. http://www.ijcmas.com.

17. Gupta E, Dar L, Kapoor G, Broor S. The changing epidemiology of dengue in Delhi, India. Virol J. 2006;3:92.

18. Mordecai E, Cohen J, Evans MV, Gudapati P, Johnson LR, Miazgowicz K. et al. Temperature determines Zika, dengue and chikungunya transmission potential in the Americas. bioRxiv. 2016;63735.

19. Mark RD, Tai-Ho C, Thane HW, Ann MP, Jacob LK, Robert SL, Moses P, Maria M, Stacey H, Christine D, Laurent G, Anne G, Martin B, Amy JL, Janeen L, Olga K, Amanda P, Brad JB, Marc F, Edward B. Zika virus outbreak on Yap Island, federated states of Micronesia. N Engl J Med. 2009:360:2536-43.

20. Oehler E, Watrin L, Larre P, Leparc-Goffart I, Lastere S, Valour F. Zika virus infection complicated by Guillain-Barre syndrome-case report, French Polynesia. Euro Surveill. 2014;19:20720.

\section{Publisher's Note}

Springer Nature remains neutral with regard to jurisdictional claims in published maps and institutional affiliations.
Ready to submit your research? Choose BMC and benefit from:

- fast, convenient online submission

- thorough peer review by experienced researchers in your field

- rapid publication on acceptance

- support for research data, including large and complex data types

- gold Open Access which fosters wider collaboration and increased citations

- maximum visibility for your research: over $100 \mathrm{M}$ website views per year

At BMC, research is always in progress.

Learn more biomedcentral.com/submissions 